\section{Endoscopic treatment of a choledochocele}

Choledochal cysts are bile duct anomalies that range from dilatation of the main bile duct to dilatation of the intrahepatic bile ducts (Caroli disease). The choledochocele is a cystic dilatation of the intraduodenal portion of the bile duct, and is designated type III in the Todani classification [1]; it represents less than $5 \%$ of all choledochal cysts. When the choledochocele is symptomatic, the incidence of carcinoma is estimated to be $2.5 \%$ and this risk increases with age [2]. Treatment by a single endoscopic sphincterotomy does not remove the risk of malignancy.

A 58-year-old woman, with a history of cholecystectomy, presented with acute pancreatitis. The etiological investigation found a choledochocele on magnetic resonance cholangiopancreatography. She was referred to North Hospital for endoscopic resection of the choledochocele.

Endoscopic retrograde cholangiopancreatography (ERCP) showed a 1.0-cm cystic mass to the proximal side of the major papilla, which suggested a type IIIA choledochocele ( Video 1 ). In the first step, a $25 \times 55 \mathrm{~mm}$ snare (Cook Medical, Bloomington, Indiana, USA) was deployed around the choledochocele. The snare was adjusted to capture the cystic dilatation and the major papilla, and then a resection was performed using endocut mode.

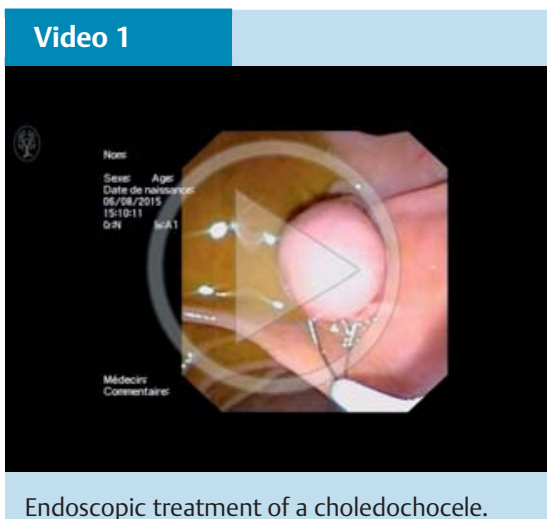

\section{Adrian Culetto, Pablo Miranda-Garcia, Juan Ignacio Tellechea, Jean-Michel Gonzalez, Marc Barthet}

Department of Gastroenterology, Public Assistance Hospitals of Marseille, North Hospital, Marseille, France

\section{References}

1 Todani T, Watanabe Y, Narusue $M$ et al. Congenital bile duct cysts: classification, operative procedures, and review of thirty-seven cases including cancer arising from choledochal cyst. Am J Surg 1977; 134: 263 - 269

2 Law R, Topazian M. Diagnosis and treatment of choledochoceles. Clin Gastroenterol Hepatol 2014; 12: 196-203

In the second step, the bile duct was cannulated using a CannulaTome (Cook Medical) in order to place a $10 \mathrm{Fr} \times 9 \mathrm{~cm}$ plastic biliary stent (Cook Medical) following biliary sphincterotomy. The pancreatic duct was then cannulated and a $5 \mathrm{Fr} \times 3 \mathrm{~cm}$ plastic stent (Cook Medical) was placed. The procedure was performed using carbon dioxide insufflation. The procedure was effective at preventing post-ERCP pancreatitis. The resection was performed without complication. The choledochocele was resected completely, and was $11 \mathrm{~mm}$ long in the major axis. Histological analysis confirmed the presence of a cystic lesion, with part duodenal and part biliary epithelia, and no tumor or dysplasia evident

\section{Bibliography}

Dol http://dx.doi.org/

10.1055/s-0042-114428

Endoscopy 2016; 48: E286

(c) Georg Thieme Verlag KG

Stuttgart · New York

ISSN 0013-726X

\section{Corresponding author}

\section{Adrian Culetto, MD}

Department of Gastroenterology

Public Assistance Hospitals of Marseille

North Hospital

Marseille 13015

France

Fax: +33-4-91961311

culetto.a@chu-toulouse.fr 